\title{
HLA Class I-Restricted T-Cell Responses May Contribute to the Control of Human Immunodeficiency Virus Infection, but Such Responses Are Not Always Necessary for Long-Term Virus Control ${ }^{\nabla}$
}

\author{
Brinda Emu, ${ }^{1,2 *}$ Elizabeth Sinclair, ${ }^{2}$ Hiroyu Hatano, ${ }^{1}$ April Ferre, ${ }^{4}$ Barbara Shacklett, ${ }^{4}$ \\ Jeffrey N. Martin, ${ }^{3}$ J. M. McCune, ${ }^{1,2}$ and Steven G. Deeks ${ }^{1}$ \\ Positive Health Program, Department of Medicine, San Francisco General Hospital, University of California, San Francisco, \\ California ${ }^{1}$; Division of Experimental Medicine, University of California, San Francisco, California ${ }^{2}$; Department of \\ Epidemiology and Biostatistics, University of California, San Francisco, California ${ }^{3}$; and Department of \\ Microbiology and Immunology, University of California, Davis, California ${ }^{4}$
}

Received 4 October 2007/Accepted 12 March 2008

\begin{abstract}
A rare subset of human immunodeficiency virus (HIV)-infected individuals maintains undetectable HIV RNA levels without therapy ("elite controllers"). To clarify the role of T-cell responses in mediating virus control, we compared HLA class I polymorphisms and HIV-specific T-cell responses among a large cohort of elite controllers (HIV-RNA < 75 copies/ml), "viremic" controllers (low-level viremia without therapy), "noncontrollers" (high-level viremia), and "antiretroviral therapy suppressed" individuals (undetectable HIV-RNA levels on antiretroviral therapy). The proportion of $\mathrm{CD4}^{+}$and $\mathrm{CD8}^{+} \mathrm{T}$ cells that produce gamma interferon (IFN- $\gamma$ ) and interleukin-2 (IL-2) in response to Gag and Pol peptides was highest in the elite and viremic controllers $(P<0.0001)$. Forty percent of the elite controllers were HLA-B $* 57$ compared to twenty-three percent of viremic controllers and nine percent of noncontrollers $(P<0.001)$. Other HLA class I alleles more common in elite controllers included HLA-B $* 13$, HLA-B $* 58$, and HLA-B*81 $(P<0.05$ for each). Within elite and viremic controller groups, those with protective class I alleles had higher frequencies of Gag-specific $\mathrm{CD8}^{+}$ $T$ cells than those without these alleles $(P=0.01)$. Noncontrollers, with or without protective alleles, had low-level $\mathrm{CD8}^{+}$responses. Thus, certain HLA class I alleles are enriched in HIV controllers and are associated with strong Gag-specific $\mathrm{CD8}^{+} \mathrm{IFN}-\gamma^{+} \mathrm{IL}_{-2}{ }^{+} \mathrm{T}$ cells. However, the absence of evidence of $\mathrm{T}$ cell-mediated control in many controllers suggests the presence of alternative mechanisms for viral control in these individuals. Defining mechanisms for virus control in "non-T-cell controllers" might lead to insights into preventing HIV transmission or preventing virus replication.
\end{abstract}

The vast majority of antiretroviral-untreated human immunodeficiency virus (HIV)-infected individuals progress to AIDS within 10 to 15 years of infection. Approximately 5\% of individuals remain asymptomatic and maintain $\mathrm{CD} 4^{+} \mathrm{T}$ cells at $>500 / \mathrm{ml}$ for 10 or more years ("long-term nonprogressors") (40). Factors known to be associated with immunologic nonprogression include those related to both the host (e.g., HIVspecific T-cell responses and allelic variation within chemokines and chemokine receptor genes) and the virus (e.g., reduced fitness and mutations or deletions in accessory genes) $(7,8,43,50)$. These mechanisms may not be completely protective given that most long-term nonprogressors have evidence of ongoing viral replication and a slow but measurable rate of immune progression $(19,33,49,57)$.

There is growing recognition that a small subset of HIVinfected individuals may be able to more fully control HIV replication indefinitely. These individuals (often referred to as "elite controllers") are HIV seropositive and maintain undetectable plasma HIV RNA levels in the absence of antiretro-

* Corresponding author. Mailing address: Positive Health Program and Division of Experimental Medicine, Department of Medicine, Box 1234, 1001 Potrero Ave., Bldg. 3, San Francisco, CA 92110. Phone: (415) 206-8132. Fax: (415) 206-8091. E-mail: brinda.emu@ucsf.edu.

${ }^{\nabla}$ Published ahead of print on 19 March 2008. viral therapy (ART) $(3,5,11,14,32,46)$. The proportion of HIV-infected individuals who are able to naturally control HIV to this degree over a period of years has not been well defined but is likely to be $\leq 1 \%(26,32)$.

Several recent studies have attempted to elucidate T-cell responses in elite controllers. A recent report has shown that $\mathrm{CD}^{+} \mathrm{T}$ cells from elite controllers are able to efficiently control viral replication and to eliminate $\mathrm{HIV}$-infected $\mathrm{CD}^{+}{ }^{+} \mathrm{T}$ cells in a cell-contact-dependent manner (53). Another report found that the proliferative potential of $\mathrm{CD}^{+} \mathrm{T}$ cells was much higher in elite controllers than in noncontrollers, while other researchers have found that controllers were highly enriched for $\mathrm{CD}^{+} \mathrm{T}$ cells that produce multiple cytokines (e.g., gamma interferon [IFN- $\gamma$ ], interleukin [IL-2], tumor necrosis factor alpha, and macrophage inflammatory protein $1 \beta$ ), as well as CD107a (a marker of perforin degranulation), in response to stimulation with HIV peptides $(5,38)$. Since each of these studies was cross-sectional in design, it is difficult to determine whether the low-level viremia was a consequence or a cause of the observed high-level T-cell responses.

Perhaps the strongest evidence that an adaptive T-cell response can contribute to the control of HIV in vivo is the consistent observation that certain HLA class I alleles are strongly predictive of viral load set point. For instance, HLA- 
B*5701 has been consistently shown to be associated with slow disease progression and is also highly enriched in elite controllers $(15,32,39)$. The HLA-B*27 allele was also found to be associated with delayed disease progression, but since the ability of this allele to prevent disease progression is only apparent in late-stage disease, it is less likely that it mediates its influence via control of HIV replication (16). It is even unclear whether HLA-B*5701-which is strongly associated with viral control-mediates its effect entirely via HIV-specific $\mathrm{CD}^{+}$ T-cell responses. Although individuals with HLA-B*5701 often mount a potent $\mathrm{T}$-cell response against one or more highly conserved viral epitopes, viral escape against these responses is not associated with viral rebound $(1,3,20,21,25,27)$. Conversely, individuals who lack evidence of cytotoxic-T-lymphocyte (CTL) escape can nonetheless exhibit high-level viral replication (37). It has recently been shown that HLA-B molecules that encode isoleucine at position 80 (Bw4 80Ile, which includes B*5701) are associated with slow disease progression when present in association with certain natural killer cell immunoglobulin-like receptors (e.g., KIR3DS1 and KIR3DL1), arguing that the apparent "protective" effects of HLA class I alleles may be mediated via natural killer responses in addition to (or instead of) T-cell responses $(36,47)$.

To date, no report has systematically studied both functional T-cell responses and HLA class I alleles in a cohort of elite controllers and noncontrollers. If functional T-cell responses are indeed protective, then these $\mathrm{CD} 8^{+}$should be strongly associated with the class I HLA alleles known to be enriched in HIV controllers. To address this hypothesis, we measured HLA class I alleles and Gag-specific $\mathrm{CD}^{+}{ }^{+}$and $\mathrm{CD}^{+}{ }^{+} \mathrm{T}$-cell responses in a cohort of 56 chronically infected elite controllers. For comparison, we carefully selected individuals who were (i) "viremic controllers" with low but detectable viral replication $(<2,000$ copies/ml), (ii) "noncontrollers" with highlevel viral loads $(>10,000$ copies/ml), and (iii) individuals that have suppressed viral loads on combination ART ("ART-suppressed"). Our results indicate that although certain HLA class I alleles are associated with highly HIV-specific $\mathrm{CD}^{+} \mathrm{T}$ cells, their presence is neither necessary nor sufficient for viral control.

\section{MATERIALS AND METHODS}

Study design. Blood was obtained from individuals enrolled in SCOPE, a prospective observational cohort study based at the University of California, San Francisco. Individuals were routinely seen at 4-month intervals, at which time HIV plasma RNA levels and $\mathrm{CD}^{+}{ }^{+} \mathrm{T}$-cell counts were obtained.

From this cohort, we selected participants meeting the criteria for one of the following four treatment groups: (i) "elite controllers," defined as ART-untreated individuals who are HIV seropositive (with an initial HIV antibody test $>2$ years prior to study entry) and three documented viral loads of $<75$ copies $/ \mathrm{ml}$ in the previous 12 months; (ii) "viremic controllers," defined as antiretroviraluntreated individuals who have steady-state plasma HIV RNA levels below 2,000 copies RNA/ml; (iii) "noncontrollers," defined as both antiretroviral-treated and untreated individuals with plasma HIV RNA levels of $>10,000$ copies $/ \mathrm{ml}$; and (iv) "ART-suppressed," defined as antiretroviral-treated individuals with undetectable plasma HIV RNA levels.

Measurements. (i) Cytokine flow cytometry. Fresh whole blood was stimulated with overlapping Gag, Env, or Pol peptide pools (15-amino-acid peptides overlapping by 11 amino acids of HIV-1 p55 Gag; BD Biosciences, San Jose, CA) for $6 \mathrm{~h}$ in the presence of brefeldin A (12). The Gag peptide pool consists of 127 peptides spanning gag p55 from SF2 strain of HIV-1 (manufactured by SynPep, Dublin, CA). The Env pool consists of 172 peptides derived from HIV-1 MN strain (SynPep), and the Pol pool consists of 248 peptides derived from the hxb2 strain of HIV-1 (manufactured by Infinity, Aston, PA). Unstimulated cells and superantigen staphylococcal enterotoxin B (Sigma Aldrich)-stimulated cells were used as negative and positive controls, respectively. Cells were fixed, permeabilized, and stained with antibodies to CD3, CD4, IFN- $\gamma$, and IL-2. The fractions of $\mathrm{CD}^{+} \mathrm{CD}^{+}$and $\mathrm{CD}^{+}{ }^{+} \mathrm{CD} 4^{-}$cells secreting IFN- $\gamma$ and/or IL-2 were determined by using a Becton Dickinson FACSCalibur and FlowJo software (TreeStar). Cells were initially defined as lymphocytes based on forward- and side-scatter profiles. The $\mathrm{T}$ cells were then identified based on the expression of CD3. $\mathrm{CD}^{+}{ }^{+} \mathrm{CD} 4^{+} \mathrm{T}$ cells and $\mathrm{CD}^{+}{ }^{+} \mathrm{CD} 4^{-} \mathrm{T}$ cells are referred to as $\mathrm{CD} 4^{+}$and $\mathrm{CD}^{+} \mathrm{T}$ cells, respectively. The fraction of $\mathrm{CD} 4^{+}$and $\mathrm{CD} 8^{+} \mathrm{T}$ cells that secrete IFN- $\gamma$ and/or IL- 2 was determined. For all values, the level of cytokine secretion observed in the negative control was subtracted in order to correct for nonspecific cytokine secretion. The median number of $\mathrm{CD}^{+}{ }^{+} \mathrm{CD} 4^{+}$and $\mathrm{CD}^{+}{ }^{+} \mathrm{CD} 4^{-}$ events collected was 10,000 . Flow cytometry gating on a representative individual is shown in Fig. 1.

(ii) HLA genotyping. Low-resolution (two-digit) and high-resolution (fourdigit) major histocompatibility complex (MHC) class I genotyping were performed by using sequence-specific PCR primers (SSP Unitray; Pel-Freez/Invitrogen, Brown Deer, WI). Briefly, genomic DNA was extracted from peripheral blood mononuclear cells (DNA blood kit; Qiagen) and subjected to sequencespecific primer amplification in a 96-well plate format. PCR amplification was performed for 30 cycles, according to the manufacturer's specifications in a thermal cycler (GeneAmp PCR 9700; Applied Biosystems). PCR products were resolved by $2 \%$ agarose gel electrophoresis. Gels were photographed, and the band patterns were recorded for analysis. Band patterns were analyzed with the aid of UniMatch software (Pel-Freez/Invitrogen). Samples giving ambiguous results were repeated for clarification.

Statistical analysis. Nonparametric tests were used for all analyses. Differences in variables between any two patient groups were analyzed by using the Mann-Whitney U test. Spearman's rank correlation was used to determine correlations between variables.

\section{RESULTS}

A total of 248 individuals underwent assessment of their HIV-specific T-cell responses using freshly collected blood: 56 "elite controllers (viral load $<75$ copies $/ \mathrm{ml}$ in the absence of ART), 77 viremic controllers (viral load $<2,000$ copies $/ \mathrm{ml}$ in the absence of ART), 37 noncontrollers (viral load $>10,000$ copies/ml), and 40 ART-suppressed individuals (viral load $<$ 75 copies/ml on ART) and $38 \mathrm{HIV}$-seronegative individuals.

Subject demographics. Table 1 shows the demographic information for the patient groups studied by four-color CFC analysis. At the time of analysis, the median plasma HIV RNA viral loads were $1.88,2.88,4.24$, and 1.88 and the median CD4 counts were 690, 564, 300, and 443 for the HIV-infected subgroups (elite controllers, viremic controllers, noncontrollers, and ART-suppressed, respectively). Elite controllers had higher CD4 T-cell counts compared to noncontrollers and ART-suppressed individuals $(P<0.0001$ for each comparison). In addition, elite controllers have been documented to be HIV seropositive for a longer period of time than all other subgroups $(P<0.05$ for all comparisons). Among individuals in the ART-suppressed group, the median length of ART therapy was 44.6 months (range, 8.5 to 94.4 months). Among the ART-suppressed group, $53 \%$ were on a protease inhibitorbased regimen, $12 \%$ were on a non-nucleoside reverse transcriptase inhibitor-based regimen, $28 \%$ had a protease inhibitor and non-nucleoside reverse transcriptase inhibitor in their regimen, and $8 \%$ were on nucleoside reverse transcriptase inhibitors alone. Enfuvirtide was part of the regimen in $10 \%$ of individuals.

Frequency of IFN- $\boldsymbol{\gamma}$ - and IL-2-producing $\mathrm{CD4}^{+} \mathrm{T}$ cells. In a recent study, we demonstrated that the ability of $\mathrm{CD} 4^{+} \mathrm{T}$ cells to secrete IL-2 and IFN- $\gamma$ in response to HIV peptides was a 


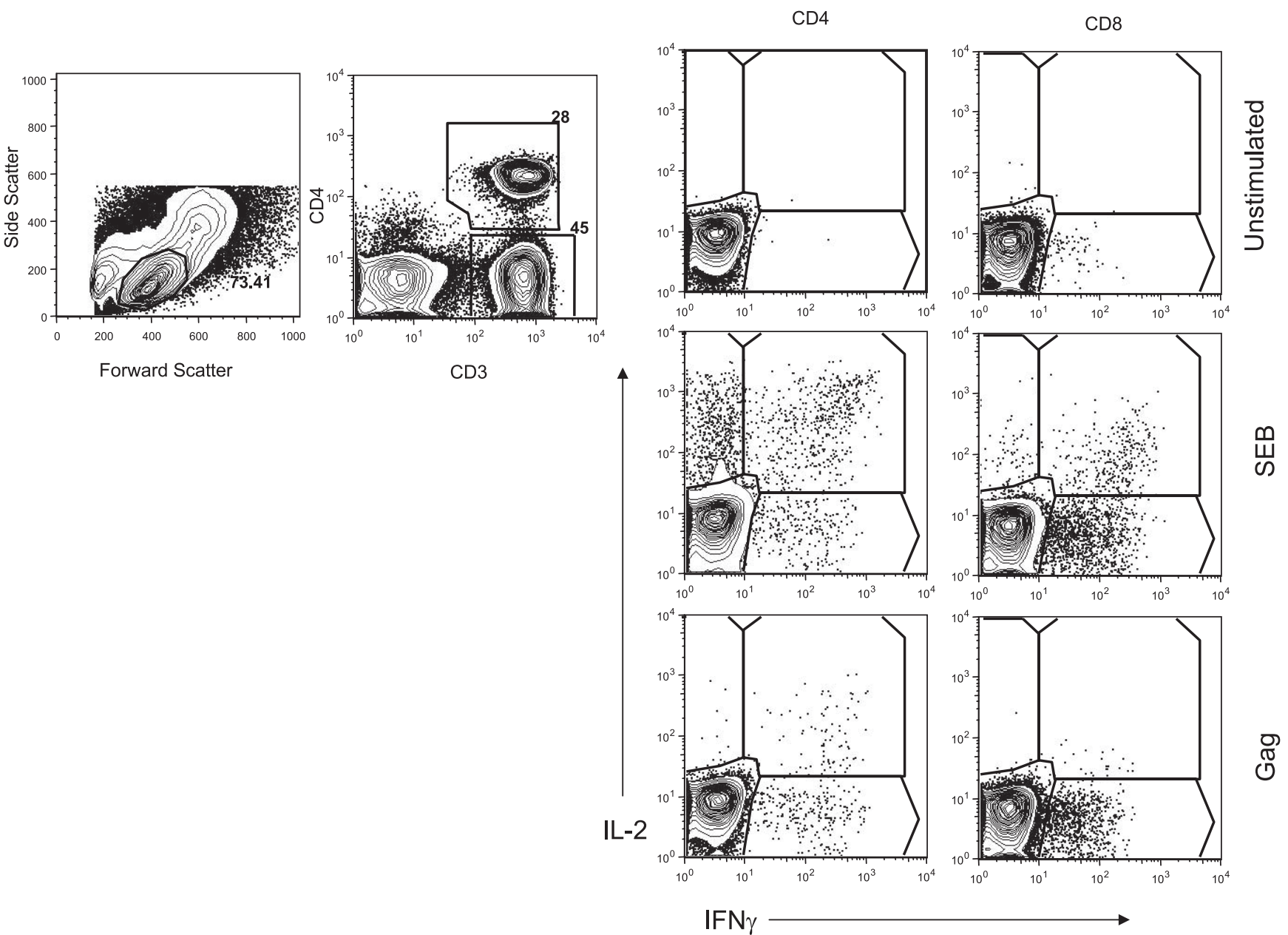

FIG. 1. Lymphocyte gating is performed by using forward and side scatter parameters. $\mathrm{CD} 3^{+} \mathrm{CD} 4^{+}$and $\mathrm{CD} 3^{+} \mathrm{CD}^{-}$populations are identified to characterize $\mathrm{CD} 4^{+}$and $\mathrm{CD} 8^{+} \mathrm{T}$-cell populations. On the right, representative flow plots of cytokine secretion for unstimulated negative control, Staphylococcal enterotoxin B-stimulated positive control and Gag peptide pools are shown.

strong and consistent correlate of virus control (14). This was particularly evident when we compared a small number of elite controllers $(n=13)$ with individuals whose virus was controlled by therapy. Here, we extended this analysis to include a larger number of individuals, and found that elite controllers $(n=56)$ have consistently higher frequencies of Gag-specific CD ${ }^{+}{ }^{\text {IFN }}-\gamma^{+}$IL-2 ${ }^{+}$T cells than ART-suppressed individuals $(n=40)(P<0.0001)$ (Fig. 2A) and consistently higher responses than noncontrollers $(n=37, P<0.0001)$. In addition, despite having a lower viral load, the elite controllers had a higher dual cytokine $\mathrm{CD} 4^{+} \mathrm{T}$-cell responses than the viremic controllers $(n=77, P=0.0002)$.

We also assessed Env-, and Pol-specific $\mathrm{CD}^{+}$and $\mathrm{CD} 8^{+}$ T-cell responses (Fig. 3). In general, there was a less robust association between these responses and virologic outcomes. Elite and viremic controllers have higher Pol-specific but not Env-specific CD $4^{+} \mathrm{IFN}_{-} \gamma^{+} \mathrm{IL}_{-} 2^{+}$responses compared to noncontrollers, although the magnitude of the Env-specific and Pol-specific responses was much lower compared to the Gagspecific response.

TABLE 1. Baseline characteristics of subjects studied by cytokine flow cytometry ${ }^{a}$

\begin{tabular}{|c|c|c|c|c|c|c|c|}
\hline \multirow{2}{*}{ Group } & \multirow{2}{*}{$\begin{array}{l}\text { No. of } \\
\text { subjects }\end{array}$} & \multicolumn{6}{|c|}{ Median (range) } \\
\hline & & Age (yr) & Time infected (yr) & CD4 count $/ \mu \mathrm{l}$ & $\mathrm{CD} 4 \%$ & CD8 count $/ \mu \mathrm{l}$ & Log viral load \\
\hline Elite controllers & 56 & $48(28-74)$ & $19(15-25)$ & $690(116-1,650)$ & $33(10-56)$ & $890(282-2,801)$ & $1.88(1.88)$ \\
\hline Viremic controllers & 77 & $45 *(25-60)$ & $17(7-23)$ & $564 *(92-1,723)$ & $27 \dagger(3-52)$ & $1,067 *(414-3,762)$ & $2.88 \div(1.88-3.78)$ \\
\hline Noncontrollers & 37 & $45^{*}(33-63)$ & $18(6-29)$ & $300 \ddagger(24-653)$ & $12 \div(3-32)$ & $1,554 \dagger(153-4,584)$ & $4.24 \div(4.00-5.61)$ \\
\hline ART suppressed & 40 & $50(34-68)$ & $18(8-26)$ & $443 \pm(127-899)$ & $21 \pm(9-47)$ & & $1.88(1.88)$ \\
\hline
\end{tabular}

\footnotetext{
${ }^{a}$ *, $P<0.05 ; \dagger, P<0.002 ; \ddagger, P<0.0001$ (compared to the elite controller group).
} 

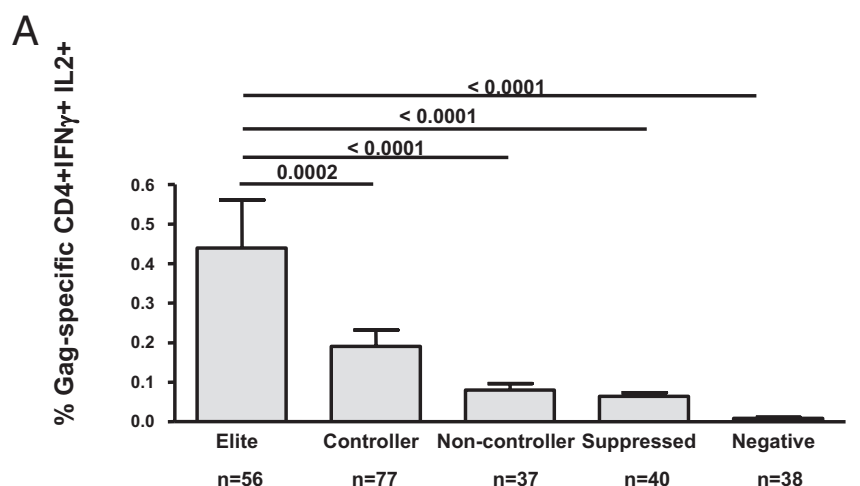

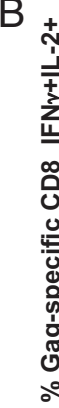
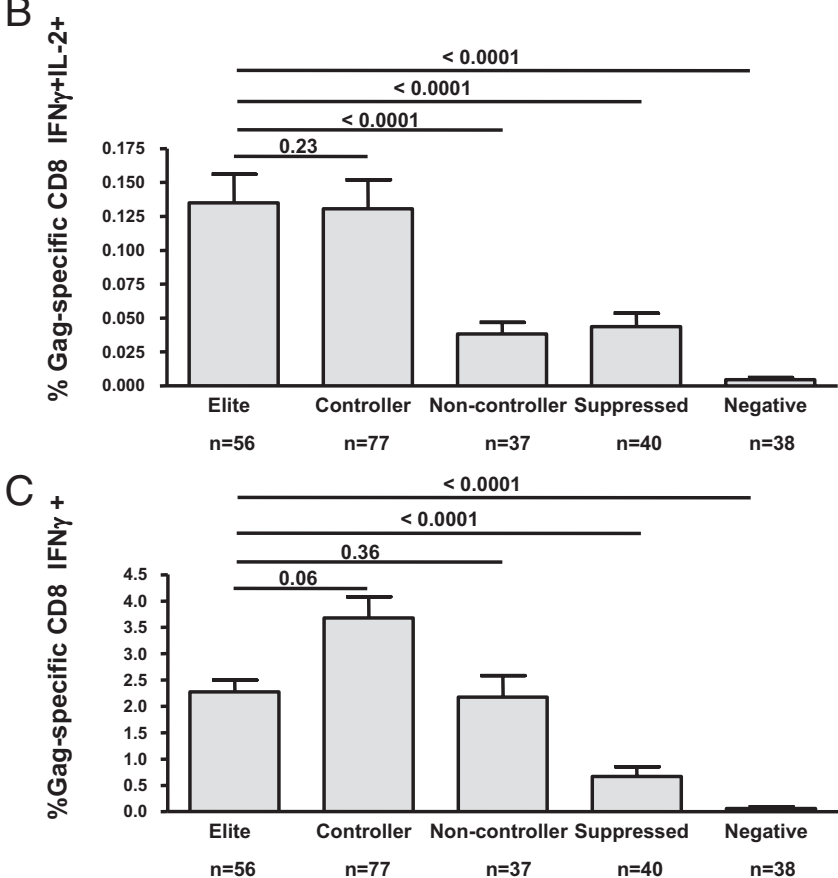

FIG. 2. Gag-specific T-cell responses among HIV-infected and uninfected individuals. Four-color flow cytometry using fresh blood stimulated for $6 \mathrm{~h}$ in the presence of brefeldin A was performed. All results are corrected for background. (A) Frequencies of $\mathrm{CD}^{+} \mathrm{CD}^{+}$lymphocytes $\left(\mathrm{CD}^{+}{ }^{+} \mathrm{T}\right.$ cells) that produce IFN- $\gamma$ and IL-2 in response to a Gag peptide pool are shown for different groups. (B and C) The frequencies of $\mathrm{CD}^{+} \mathrm{CD}^{-}\left(\mathrm{CD}^{+} \mathrm{T}\right.$ cells $)$ that produce IFN- $\gamma / \mathrm{IL}-2$ or IFN- $\gamma$ are depicted in panel B and C, respectively.

Frequency of IFN- $\boldsymbol{\gamma}$ - and IL-2-producing $\mathrm{CD8}^{+} \mathrm{T}$ cells. We have not previously reported on HIV-specific $\mathrm{CD}^{+}$T-cell responses, in part because these responses are generally less strongly associated with virologic outcomes in our studies. Here, with a greatly expanded data set, we found the frequency of $\mathrm{CD}^{+} \mathrm{T}$ cells that produce only IL-2 in an antigen-dependent manner was generally low in all groups. However, $\mathrm{CD} 8^{+}$ $\mathrm{T}$ cells that produce both IFN- $\gamma$ and IL- 2 were consistently measurable and higher in the elite and viremic controllers than the other groups. The elite controllers and viremic controllers had comparable levels of Gag-specific $\mathrm{CD}^{+} \mathrm{T}$ cells that are positive for IFN- $\gamma$ and IL-2 $(P=0.23)$, and both groups had a higher frequency of these cells than the noncontrollers $(P<0.0001)$ and ART-suppressed individuals $(P<0.0001)$. (Fig. 2B).

As has been observed by others $(2,31,56)$, the presence of
Gag-specific IFN- $\gamma$-producing $\mathrm{CD}^{+} \mathrm{T}$ cells was not associated with virus control. The level of these cells was marginally higher in the viremic controllers than the elite controllers $(P=$ $0.06)$, while there was no difference between the elite controllers and the noncontrollers $(P=0.36)$ (Fig. 2C).

With regard $\mathrm{CD}^{+}$T-cell responses to other HIV peptide pools, viremic controllers have the highest levels of Pol-specific $\mathrm{CD} 8^{+} \mathrm{IFN}-\gamma^{+}$and $\mathrm{CD} 8^{+} \mathrm{IFN}-\gamma^{+} \mathrm{IL}-2^{+}$responses (Fig. 3). Again, there were no clear trends regarding Env-specific responses among those controlling or not controlling virus. This finding is consistent with a recent study indicating that Gagrather than Env-specific T cells responses predict disease outcomes in untreated African populations during the chronic phase of HIV infection and with another recent report of HIV-specific responses among elite controllers $(30,46)$.

Heterogeneity in responses exists within elite and viremic controllers. Even though elite controllers have high numbers of Gag-specific $\mathrm{CD} 4^{+}$and $\mathrm{CD} 8^{+} \mathrm{IFN}-\gamma^{+} \mathrm{IL}-2^{+} \mathrm{T}$ cells as a group, there is heterogeneity within this group, and many elite controllers have minimal or no such Gag-specific T-cell responses (Fig. 4). We accordingly began to explore in detail the potential differences that might lie within the group of elite controllers.

Certain HLA class I alleles are enriched in controllers. The association of HLA class I alleles with functional responses in controllers compared to noncontrollers has not been systematically studied. We therefore analyzed the distribution of HLA class I alleles in 30 elite controllers, 31 viremic controllers, and 293 viremic noncontrollers and compared these data to the functional responses. Forty percent of elite controllers were HLA B*57 compared to $26 \%$ of viremic controllers and $9 \%$ of noncontrollers (Fisher exact test, $P<0.001$ ); this effect was independent of ethnicity. Other HLA class I alleles that were more common in controllers included: HLA B*13, B*58, and $\mathrm{B}^{*} 81$ ( $P<0.001$ for $\mathrm{B}^{*} 81, P<0.05$ for other alleles) (Fig. $5)$. HLA-B*27 was more common in controllers than noncontrollers (Fig. 5), but this trend did not achieve statistical significance. However, because of the consistent evidence in the literature of HLA B*27 being associated with delayed HIV disease progression $(1,24,29,34)$, it was included as a protective allele in our subsequent analyses. Overall, $60 \%$ of elite controllers, $52 \%$ of viremic controllers, and $16 \%$ of viremic noncontrollers possessed at least one of these "protective" class I alleles (HLA B*13, B*27, B*57, B*58, or B*81) $(P<$ $0.001)$.

The finding that HLA-B*5701 and other class I alleles are enriched in elite controllers is consistent with the possibility that adaptive $\mathrm{T}$-cell responses play a role in viral control in these individuals. However, it is important to note that almost one-third of controllers do not carry these "protective" alleles. Thus, the presence of a strong adaptive T-cell response may not be necessary for viral control. Reciprocally, a large proportion of noncontrollers bear these "protective" alleles and nonetheless progress virologically. Thus, the mere presence of these alleles is not sufficient to confer viral control.

We also looked for the presence of alleles that may be associated with poor virologic control. Consistent with prior reports $(9,17,54)$, the presence of both HLA B*07 and HLA $\mathrm{B}^{*} 35$ were enriched among noncontrollers, compared to both elite controllers and viremic controllers $(P<0.05$ for HLA 
\% Pol-specific CD4+IFN $\gamma+$ IL2+

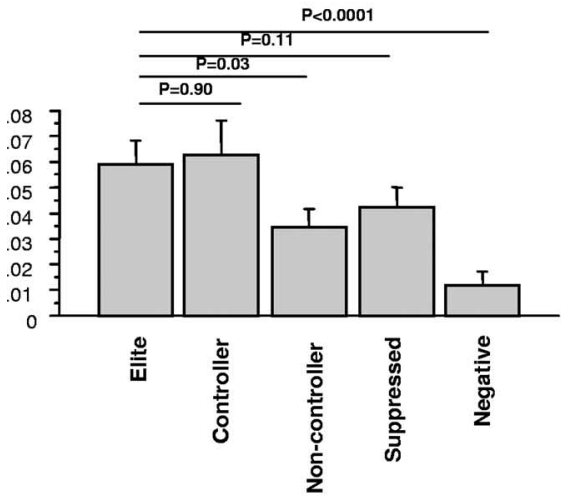

\% Env-specific CD4+IFN $\gamma+$ IL2+

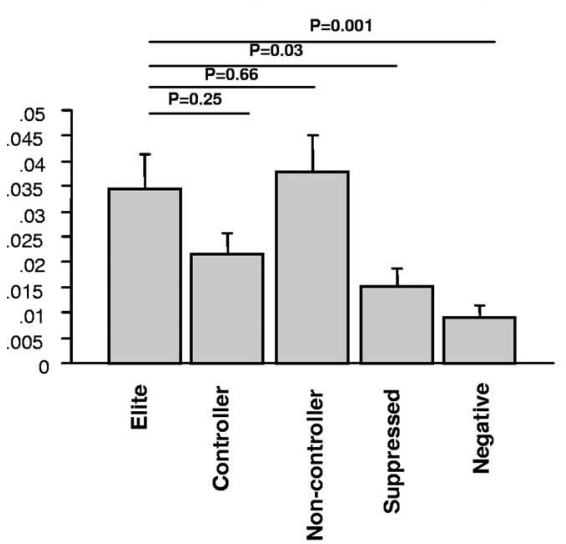

\% Pol-specific CD8+IFN $\gamma+$ IL2+

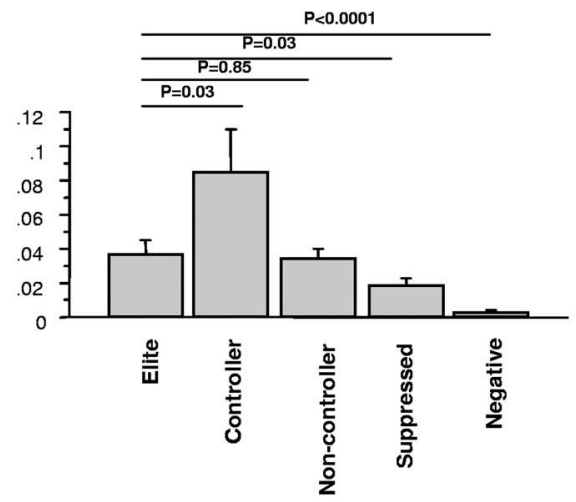

\% Env-specific CD8+IFN $\gamma+$ IL2+

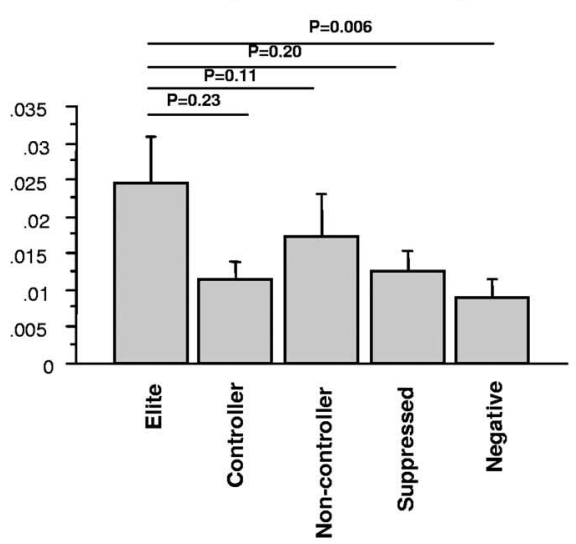

\% Pol-specific CD8+IFN $\gamma+$

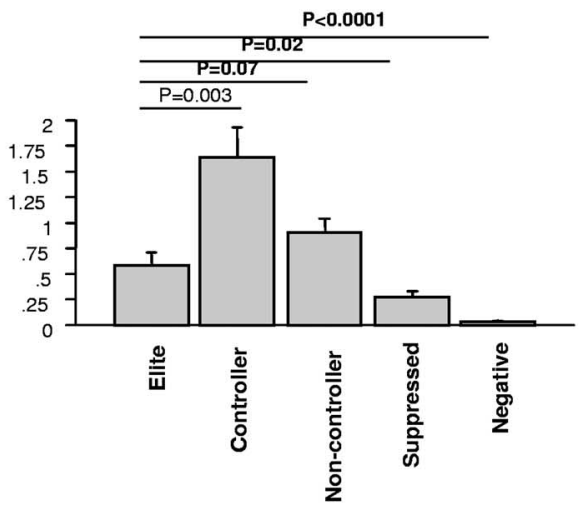

\% Env-specific CD8+IFN $\gamma+$

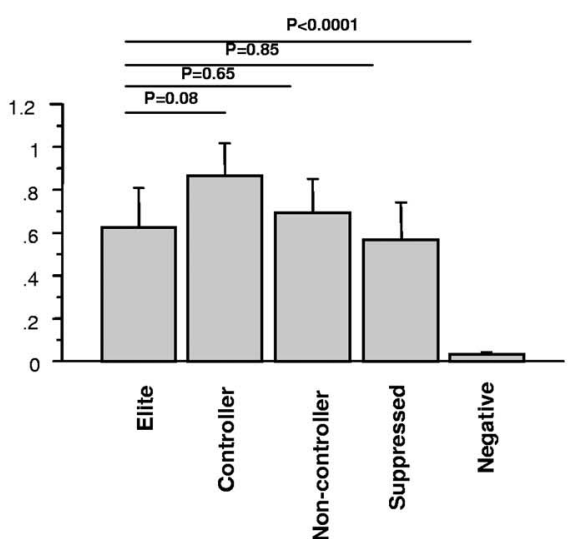

FIG. 3. Pol- and Env-specific T-cell responses among HIV-infected and uninfected individuals. Four-color flow cytometry using fresh blood stimulated for $6 \mathrm{~h}$ in the presence of brefeldin A was performed. All results are corrected for background. The top three panels represent Pol-specific responses, where the frequencies CD $4^{+} \mathrm{T}$ cells that produce IFN- $\gamma$ and IL-2, CD ${ }^{+}$T cells that produce IFN- $\gamma$ and IL-2, and $\mathrm{CD} 8^{+} \mathrm{T}$ cells that produce IFN- $\gamma$ alone are shown for different individual subject groups. Note that the scale in this figure is different from that of Fig. 2.

$\mathrm{B}^{*} 07$ and approaching statistical significance with $P=0.06$ for HLA B*35, Fig. 5).

HLA class I alleles predict $\mathrm{CD8}^{+}$HIV-specific T-cell response in controllers. We next sought to determine whether the presence of "protective" HLA class I alleles (defined as HLA $B^{*} 13, B^{*} 27, B^{*} 57, B^{*} 58$, and $B^{*} 81$ ) explained the heterogeneity of $\mathrm{CD}^{+} \mathrm{T}$-cell responses. Among elite and viremic controllers, those with a "protective" HLA allele had a significantly higher proportion of Gag-specific $\mathrm{CD} 8^{+} \mathrm{IFN}-\gamma^{+}$ IL- $2^{+}$T cells compared to those without a "protective" allele $(P=0.01)$ (Fig. 6). There was also a trend toward higher Gag-specific $\mathrm{CD}^{+}{ }^{+} \mathrm{IFN}-\gamma^{+}$responses $(P=0.07$, data not shown). These data indicate that the ability to mount a strong dual-cytokine $\mathrm{CD}^{+}$T-cell response is associated with "protective" class I alleles that confer protection against HIV replication. However, more importantly, the observation that elite controllers without protective class I alleles had low T-cell responses argues against low viremia as being the sole cause of the maintenance of HIV-specific T-cell responses.

Among noncontrollers, the presence of a "protective" allele was not associated with a high frequency of HIV-specific $\mathrm{CD}^{+}$T-cell responses (Fig. 6). Furthermore, controllers with a protective allele had higher $\mathrm{CD}^{+}$T-cell responses than noncontrollers with a protective allele $(P=0.002)$. There was, as expected, no clear association between class I alleles and the Gag-specific CD4 ${ }^{+}$T-cell response (Fig. 6).

\section{DISCUSSION}

A rare but important host response to HIV is exemplified by individuals ("elite controllers") who are able to maintain undetectable HIV RNA levels in the absence of therapy for years to decades. Here, we demonstrate that durable control of HIV among elite controllers is strongly associated with the presence of Gag-specific CD4 ${ }^{+}$IFN- $\gamma^{+}$IL- $2^{+} \mathrm{T}$ cells and to a lesser extent Gag-specific CD8 ${ }^{+} \mathrm{IFN}-\gamma^{+} \mathrm{IL}-2^{+} \mathrm{T}$ cells. Our findings show that controllers are enriched for certain class I HLA alleles (i.e., HLA B*13, B*57, B*58, and B*81) and that the presence of these alleles predicts the Gag-specific $\mathrm{CD}^{+} \mathrm{T}$-cell response. Importantly, we also demonstrate that strong Gagspecific T-cell responses are not present in a subgroup of individuals with excellent viral control and that many individuals control viral replication without "protective" HLA alleles or strong $\mathrm{CD}^{+}$T-cell responses. We have also shown that Pol- 


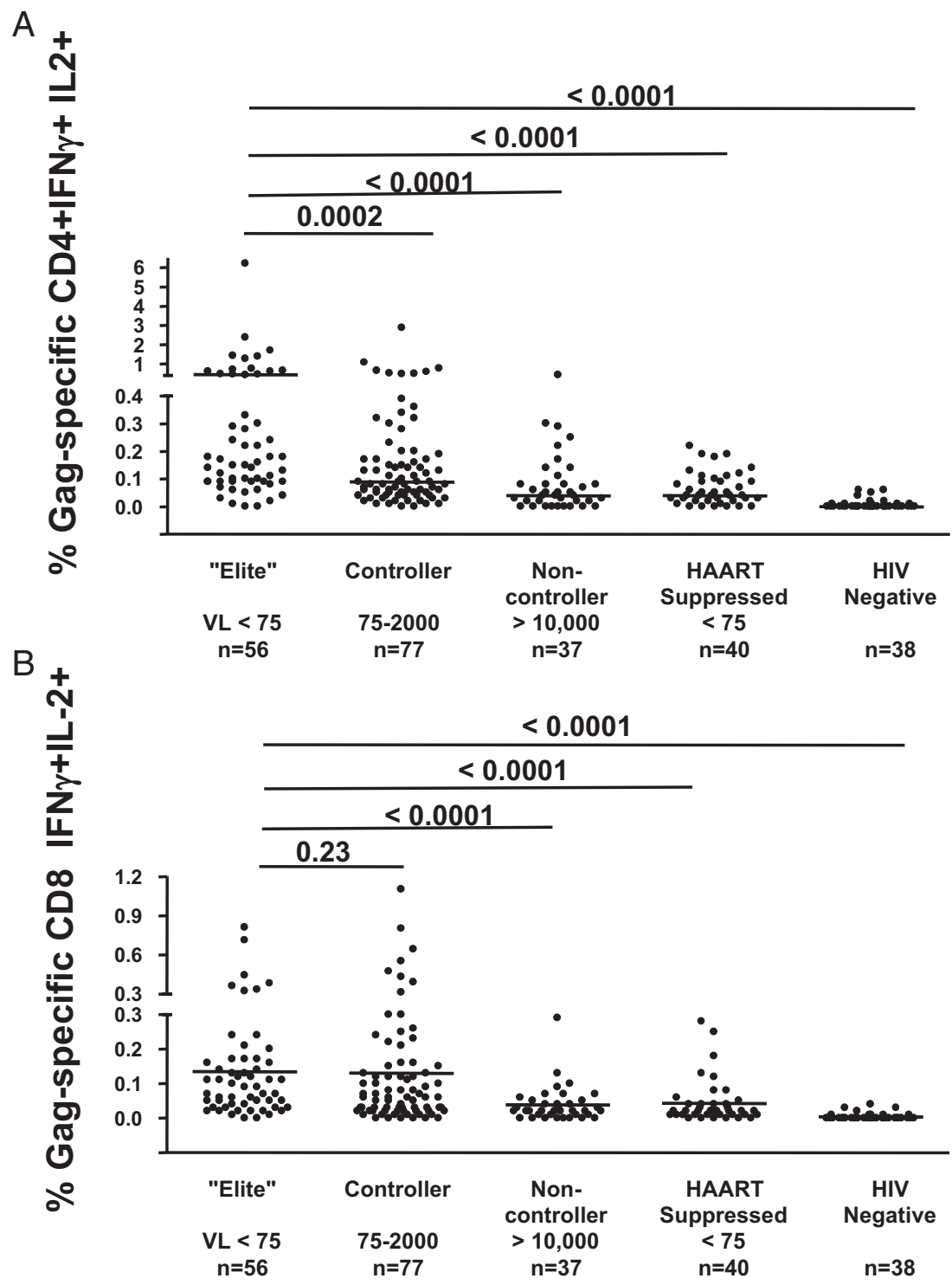

FIG. 4. Distribution of individual responses to Gag-peptide pools. Frequency of Gag-specific CD $4^{+} \mathrm{IFN}-\gamma^{+} \mathrm{IL}-2^{+}$and $\mathrm{CD} 8^{+} \mathrm{IFN}-\gamma^{+} \mathrm{IL}-2^{+} \mathrm{T}$

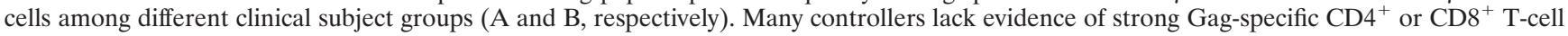
responses.

specific responses, though of a much lower magnitude than Gag-specific responses, are higher in the groups controlling viremia in the absence of therapy. Env-specific responses do not consistently correlate with viral control in this chronically HIV-infected cohort. These latter findings are consistent with findings in the simian immunodeficiency virus model where $\mathrm{CD}^{+} \mathrm{T}$ cells recognizing Gag and Pol epitopes were able to recognize infected cells earlier after infection compared to Env- or Nef-specific CD8 ${ }^{+} \mathrm{T}$ cells $(51,52)$, as well as in another recent report of elite controllers (46). Collectively, these data provide strong evidence that HIV-specific $\mathrm{T}$ cells are associated with virus control in some, but not all, elite and low-level viremic controllers. It also suggests that HIV-specific $\mathrm{T}$ cells may not be necessary for viral control.

Why do some individuals maintain such tight viral control in the absence of therapy, whereas the vast majority of individuals exhibit high levels of viral replication? There are at least several potential mechanisms. One possibility is that elite controllers eradicated replication-competent virus upon first exposure and no longer harbor intact viral genomes. This would have left them seropositive but without active viral replication. In a recent report, Bailey et al. used ultrasensitive reverse transcription-PCR methods to find both plasma viral sequences and $\mathrm{CD}^{+}{ }^{+} \mathrm{T}$-cell-associated proviral DNA in most elite controllers with viral loads $<50$ copies/ml, arguing against this hypothesis (3). A second possibility is that elite controllers harbor a replication-impaired virus and that the reduction in viral fitness/ pathogenicity allows for a stronger and more effective host response. Such a scenario is reminiscent of our prior studies in treated patients with drug-resistant HIV ("partial controllers on ART"), wherein it appeared that treatment-associated reductions in viral fitness led to activation and preservation of 


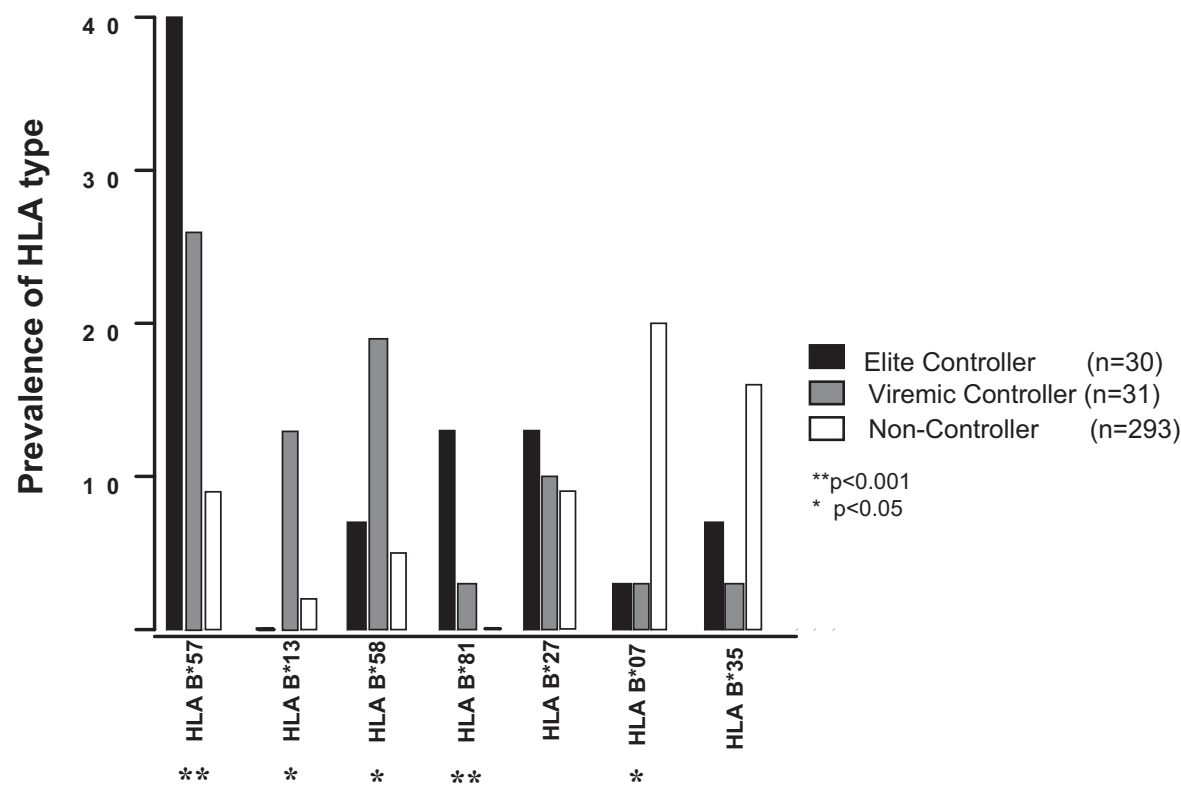

FIG. 5. Distribution of HLA class I alleles. The proportion of individuals among elite controllers $(n=30)$, viremic controllers $(n=31)$, and noncontrollers $(n=293)$ who have the corresponding allele is shown. Only the HLA class I alleles significantly enriched among elite and viremic controllers are shown.

HIV-specific immunity $(12,14)$. We have not formally ruled out this possibility, although others have shown that many controllers harbor replication-competent virus (6). A third possibility is that although there is little viral replication within the peripheral blood compartment, there may be high-level replication in other compartments, such as in the gut or central nervous system, with subsequent maintenance of a potent HIV-specific response. The last possibility, and the one that we address here, is that virus replication is controlled by an effective host immune response.

Defining the role of HIV-specific T-cell responses in humans is challenging. It is difficult to infer whether strong HIV-specific responses result in viral control or whether low-level viral replication results in preservation of HIV-specific T-cell responses $(28,42)$. The more likely scenario is that there is a delicate balance between antigenic stimulation and T-cell responses. Low-level viral replication may allow for the maintenance of HIV-specific T cells that are capable of IL-2 production and proliferation. Whether the initial decrease in viral load is due to the presence of these T cells or other features of the immune system cannot be addressed with cross-sectional studies as presented here and elsewhere $(14,22,46)$. However, to address the issue of whether the presence of HIV-specific T cells is simply a consequence of viral control, we analyzed dual cytokine (IFN- $\gamma$ and IL-2) responses in those who were ART suppressed and compared these individuals to our elite con-

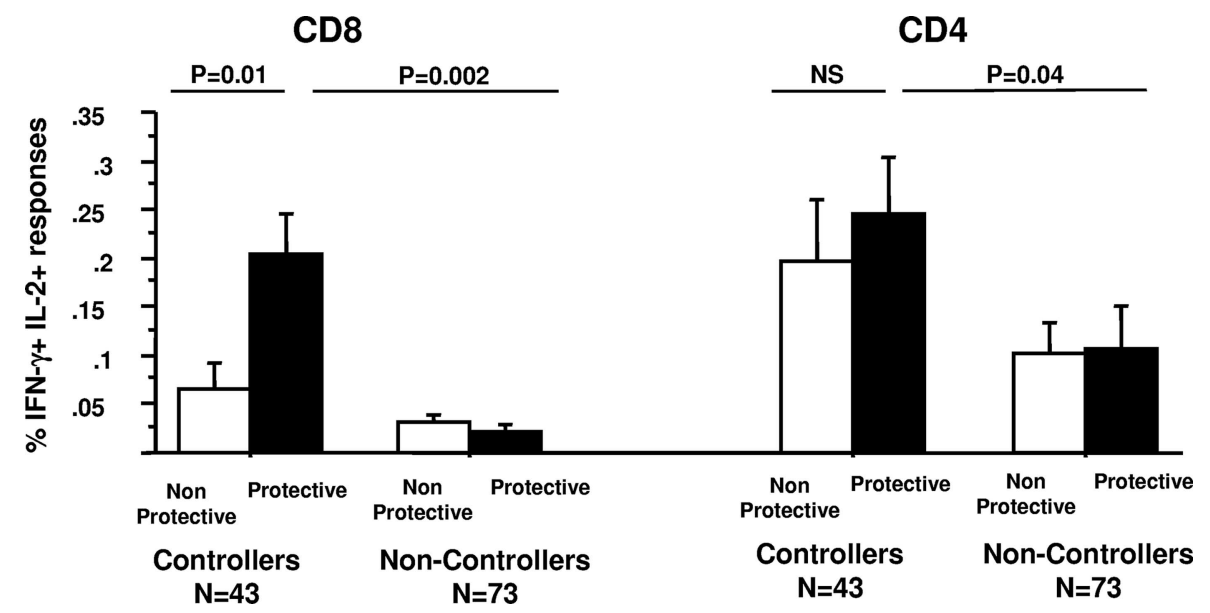

FIG. 6. HLA type and Gag-specific T-cell responses. The frequency of Gag-specific CD $8^{+}$and $\mathrm{CD} 4^{+}$IFN- $\gamma^{+}$IL- $2^{+}$T-cell responses among controllers and noncontrollers with protective and without protective HLA alleles is shown. Protective alleles are defined as HLA-B*13, HLA-B*27, HLA-B*57, HLA-B*58, and HLA-B*81. 
trollers. Despite low levels of viral replication in both groups, elite controllers consistently had higher levels of HIV-specific $\mathrm{CD}^{+}{ }^{+}$that produce IFN- $\gamma$ and IL-2 compared to ART-suppressed individuals. Similar trends were observed within the $\mathrm{CD}^{+} \mathrm{T}$-cell subset. Many have argued that it is in fact viral control itself that allows for the presence of memory cells and thus IL-2 production, but the absence of HIV-specific IL-2 production among ART-suppressed individuals suggests that this is not always the case. It has also been suggested that the absence of T-cell responses in ART-suppressed individuals may be due to immunologic damage during previous high-level viremia (46). However, this is unlikely to be the case given that, upon ART discontinuation or failure, HIV-specific T-cell responses return $(18,41,44,45)$.

One of the main findings of the present study is the fact that, while elite controllers have higher HIV-specific IFN- $\gamma^{+} \mathrm{IL}_{-} 2^{+}$ $\mathrm{T}$-cell responses as a whole, there is significant heterogeneity within this group. Many subjects exhibit no or only limited HIV-specific T-cell responses. This heterogeneity among controllers is predicted by the class I HLA profile, supporting that HLA mediates its effect via a strong and potent $\mathrm{CD}^{+} \mathrm{T}$-cell response (i.e., those with "protective" HLA class I alleles have higher frequency $\mathrm{CD}^{+}$T-cell responses than those without these alleles). However, approximately a third of the elite controllers in this cohort lacked a "protective" class I allele and had limited Gag-specific CD ${ }^{+} \mathrm{T}$-cell responses but still were able to maintain excellent viral control. Furthermore, controllers with protective class I alleles did not have higher $\mathrm{CD} 4^{+} \mathrm{T}$ counts (data not shown). Thus, the presence of a "protective" HLA allele and a strong adaptive T-cell response does not appear to be necessary for achieving durable viral control. Of note, a recent report by Pereyra et al. failed to detect an association between the presence of certain HLA alleles and the magnitude of HIV-specific responses between elite controllers with protective HLA alleles. This lack of an association may be due to their use of an enzyme-linked immunospot assay (which only allows detection of a single cytokine) and the use of whole peripheral blood mononuclear cells (which does not allow for the delineation of a $\mathrm{CD}^{+} \mathrm{T}$-cell response from a $\mathrm{CD}^{+}$T-cell response) (46).

Elite controllers with "protective" class I alleles also had a higher $\mathrm{CD}^{+} \mathrm{T}$-cell response than noncontrollers with these same alleles. Several possibilities arise to explain this finding. One possibility is that CTL escape in noncontrollers renders the class I-restricted $\mathrm{CD} 8^{+} \mathrm{T}$-cell response less robust. Several groups have addressed this possibility among HLA-B*57 expressing individuals and failed to find a strong association between CTL escape mutations and either virus control or T-cell responses $(3,37,58)$. Another possibility is that other factors may be required in addition to a potent $\mathrm{T}$-cell response. For instance, the combination of HLA-Bw4-80I (HLA B alleles, including $\mathrm{HLAB}^{*} 57$, that encode molecules that have isoleucine at position 80) and killer cell immunoglobulinlike receptors (KIR) that exert a protective effect against AIDS progression (KIR3DS1 and KIR3DL1) (36). This and other features of the innate immune response, some linked to class I alleles, may play an integral role in viral control. A third possibility is that there are factors that negate effects conferred by "protective" class I alleles. These may include the absence of a $\mathrm{CD} 4^{+} \mathrm{T}$-cell response or altered function of other arms of the immune system. Regardless of the exact reason for this finding, it is clear that the mere presence of a "protective" class I HLA allele does not appear to be sufficient for effective viral control.

Several limitations with regard to our measurements deserve mention. First, the assays used in the present study focused on responses directed against a limited numbers of peptide pools (Gag, Pol, and Env), which were derived from consensus rather than autologous sequences. It is also possible, as recently suggested, that although $\mathrm{CD}^{+} \mathrm{T}$ cells may secrete cytokines in response to cells loaded with synthetic peptides, this may not correlate with the ability of $\mathrm{CD}^{+} \mathrm{T}$ cells to recognize the same epitope in the context of an HIV-infected cell $(4,13)$. Second, we measured responses in blood rather than in tissues, where most viral replication occurs. Third, we only measured a focused outcome: the ability to produce IFN- $\gamma$ and IL- 2 after limited exposure to peptides ex vivo. The use of additional cytokines could potentially have increased the antigen-specific response detected. We do not believe that these assay limitations negate our fundamental observation, which is that the levels of Gag- and Pol-specific T cells, as defined by the production of IL- 2 and IFN- $\gamma$, are consistently higher in elite controllers than in other patient groups.

One of our primary conclusions pertains to the much higher $\mathrm{T}$-cell response in those with undetectable viral loads in absence of therapy compared to those with undetectable viral loads in presence of therapy, which we argue is evidence that the host T-cell response is not simply a consequence of viral control. This argument assumes that the two groups have comparable levels of viral replication, which may not be true. The level of residual viral replication in "elite" controllers is not known and the degree to which virus replication occurs during effective ART remains highly controversial (10, 23, 35, 48, 55). As has been observed with ART-suppressed patients (35), most of our elite controllers have low but measurable HIV RNA levels, and there is no apparent association between the level of plasma viremia and the T-cell responses (unpublished data).

In summary, elite and viremic controllers are individuals with chronic HIV infection who are able to maintain viral replication at low levels in the absence of therapy. Here, we show that a robust HIV-specific T-cell response is maintained for many, but not all, elite controllers and that this response is linked to "protective" class I HLA alleles. However, a significant subset of controllers lacks evidence for T-cell control. The clear identification of such individuals using the approach outlined here may allow for more focused studies regarding novel mechanisms of control.

\section{ACKNOWLEDGMENTS}

This study was supported in part by grants from the NIAID (AI052745 to B.E.; AI057020 to B.L.S.; AI47062 and AI43864 to J.M.M.; and AI055273 and AI44595 to S.G.D.), AmFAR (106710-40RGRL), the California AIDS Research Center (CC99-SF, ID01-SF049), the Center for AIDS Prevention Studies (P30 MH62246), and the UCSF CTSI (UL1 RR024131-01). J.M.M. is a recipient of the Burroughs Wellcome Fund Clinical Scientist Award in Translational Research and the NIH Director's Pioneer Award Program, part of the NIH Roadmap for Medical Research, funded through grant DPI OD00329. 


\section{REFERENCES}

1. Altfeld, M., E. T. Kalife, Y. Qi, H. Streeck, M. Lichterfeld, M. N. Johnston, N. Burgett, M. E. Swartz, A. Yang, G. Alter, X. G. Yu, A. Meier, J. K. Rockstroh, T. M. Allen, H. Jessen, E. S. Rosenberg, M. Carrington, and B. D. Walker. 2006. HLA alleles associated with delayed progression to AIDS contribute strongly to the initial CD $8^{+} \mathrm{T}$ cell response against HIV-1. PLoS Med. 3:e403.

2. Bailer, R. T., A. Holloway, J. Sun, J. B. Margolick, M. Martin, J. Kostman, and L. J. Montaner. 1999. IL-13 and IFN- $\gamma$ secretion by activated T cells in HIV-1 infection associated with viral suppression and a lack of disease progression. J. Immunol. 162:7534-7542.

3. Bailey, J. R., T. M. Williams, R. F. Siliciano, and J. N. Blankson. 2006. Maintenance of viral suppression in HIV-1-infected HLA-B*57 $7^{+}$elite suppressors despite CTL escape mutations. J. Exp. Med. 203:1357-1369.

4. Bennett, M. S., H. L. Ng, A. Ali, and O. O. Yang. 2008. Cross-clade detection of HIV-1-specific cytotoxic T lymphocytes does not reflect cross-clade antiviral activity. J. Infect. Dis. 197:390-397.

5. Betts, M. R., M. C. Nason, S. M. West, S. C. De Rosa, S. A. Migueles, J. Abraham, M. M. Lederman, J. M. Benito, P. A. Goepfert, M. Connors, M. Roederer, and R. A. Koup. 2006. HIV nonprogressors preferentially maintain highly functional HIV-specific $\mathrm{CD}^{+} \mathrm{T}$ cells. Blood 107:47814789 .

6. Blankson, J. N., J. R. Bailey, S. Thavil, H. C. Yang, K. Lassen, J. Lai, S. K. Gandhi, J. D. Siliciano, T. M. Williams, and R. F. Siliciano. 2007. Isolation and characterization of replication-competent human immunodeficiency virus type 1 from a subset of elite suppressors. J. Virol. 81:2508-2518.

7. Buchbinder, S., and E. Vittinghoff. 1999. HIV-infected long-term nonprogressors: epidemiology, mechanisms of delayed progression, and clinical and research implications. Microbes Infect. 1:1113-1120.

8. Cao, Y., L. Qin, L. Zhang, J. Safrit, and D. D. Ho. 1995. Virologic and immunologic characterization of long-term survivors of human immunodeficiency virus type 1 infection. N. Engl. J. Med. 332:201-208.

9. Carrington, M., G. W. Nelson, M. P. Martin, T. Kissner, D. Vlahov, J. J. Goedert, R. Kaslow, S. Buchbinder, K. Hoots, and S. J. O'Brien. 1999. HLA and HIV-1: heterozygote advantage and B*35- $\mathrm{Cw}^{*} 04$ disadvantage. Science 283:1748-1752.

10. Chun, T. W., D. C. Nickle, J. S. Justement, D. Large, A. Semerjian, M. E. Curlin, A. O'Shea, M. C. W. Hallahan, M. Daucher, D. J. Ward, S. Moir, J. I. Mullins, C. Kovacs, and A. S. Fauci. 2005. HIV-infected individuals receiving effective antiviral therapy for extended periods of time continually replenish their viral reservoir. J. Clin. Investig. 115:3250-3255.

11. Deeks, S., and B. Walker. 2007. Human immunodeficiency virus controllers: mechanisms of durable virus control in the absence of antiretroviral therapy. Immunity 27:406-416.

12. Deeks, S. G., J. N. Martin, E. Sinclair, J. Harris, T. B. Neilands, H. T. Maecker, E. Hagos, T. Wrin, C. J. Petropoulos, B. Bredt, and J. M. McCune. 2004. Strong cell-mediated immune responses are associated with the maintenance of low-level viremia in antiretroviral-treated individuals with drugresistant human immunodeficiency virus type 1. J. Infect. Dis. 189:312-321.

13. D'Souza, M. P., and M. Altfeld. 2008. Measuring HIV-1-specific T cell immunity: how valid are current assays? J. Infect. Dis. 197:337-339.

14. Emu, B., E. Sinclair, D. Favre, W. J. Moretto, P. Hsue, R. Hoh, J. N. Martin, D. F. Nixon, J. M. McCune, and S. G. Deeks. 2005. Phenotypic, functional, and kinetic parameters associated with apparent T-cell control of human immunodeficiency virus replication in individuals with or without antiretroviral treatment. J. Virol. 79:14169-14178.

15. Fellay, J., K. V. Shianna, D. Ge, S. Colombo, B. Ledergerber, M. Weale, K. Zhang, C. Gumbs, A. Castagna, A. Cossarizza, A. Cozzi-Lepri, A. De Luca, P. Easterbrook, P. Francioli, S. Mallal, J. Martinez-Picado, J. M. Miro, N. Obel, J. P. Smith, J. Wyniger, P. Descombes, S. E. Antonarakis, N. L. Letvin, A. J. McMichael, B. F. Haynes, A. Telenti, and D. B. Goldstein. 2007. A whole-genome association study of major determinants for host control of HIV-1. Science 317:944-947.

16. Gao, X., A. Bashirova, A. K. Iversen, J. Phair, J. J. Goedert, S. Buchbinder, K. Hoots, D. Vlahov, M. Altfeld, S. J. O'Brien, and M. Carrington. 2005. AIDS restriction HLA allotypes target distinct intervals of HIV-1 pathogenesis. Nat. Med. 11:1290-1292.

17. Gao, X., G. W. Nelson, P. Karacki, M. P. Martin, J. Phair, R. Kaslow, J. J. Goedert, S. Buchbinder, K. Hoots, D. Vlahov, S. J. O'Brien, and M. Carrington. 2001. Effect of a single amino acid change in MHC class I molecules on the rate of progression to AIDS. N. Engl. J. Med. 344:1668-1675.

18. Garcia, F., M. Plana, G. M. Ortiz, S. Bonhoeffer, A. Soriano, C. Vidal, A Cruceta, M. Arnedo, C. Gil, G. Pantaleo, T. Pumarola, T. Gallart, D. F. Nixon, J. M. Miro, and J. M. Gatell. 2001. The virological and immunological consequences of structured treatment interruptions in chronic HIV-1 infection. AIDS 15:F29-F40.

19. Goudsmit, J., J. A. Bogaards, S. Jurriaans, H. Schuitemaker, J. M. Lange, R. A. Coutinho, and G. J. Weverling. 2002. Naturally HIV-1 seroconverter with lowest viral load have best prognosis, but in time lose control of viraemia. AIDS 16:791-793.

20. Goulder, P. J., C. Brander, K. Annamalai, N. Mngqundaniso, U. Govender,
Y. Tang, S. He, K. E. Hartman, C. A. O'Callaghan, G. S. Ogg, M. A. Altfeld, E. S. Rosenberg, H. Cao, S. A. Kalams, M. Hammond, M. Bunce, S. I. Pelton, S. A. Burchett, K. McIntosh, H. M. Coovadia, and B. D. Walker. 2000. Differential narrow focusing of immunodominant human immunodeficiency virus gag-specific cytotoxic T-lymphocyte responses in infected African and Caucasoid adults and children. J. Virol. 74:5679-5690.

21. Goulder, P. J., M. Bunce, P. Krausa, K. McIntyre, S. Crowley, B. Morgan, A Edwards, P. Giangrande, R. E. Phillips, and A. J. McMichael. 1996. Novel, cross-restricted, conserved, and immunodominant cytotoxic T lymphocyte epitopes in slow progressors in HIV type 1 infection. AIDS Res. Hum. Retrovir. 12:1691-1698.

22. Harari, A., S. Petitpierre, F. Vallelian, and G. Pantaleo. 2003. Skewed representation of functionally distinct populations of virus-specific CD4 T cells in HIV-1-infected subjects with progressive disease: changes after antiretroviral therapy. Blood 103:966-972.

23. Havlir, D. V., M. C. Strain, M. Clerici, C. Ignacio, D. Trabattoni, P. Ferrante, and J. K. Wong. 2003. Productive infection maintains a dynamic steady state of residual viremia in human immunodeficiency virus type 1-infected persons treated with suppressive antiretroviral therapy for five years. J. Virol. 77:11212-11219.

24. Hendel, H., S. Caillat-Zucman, H. Lebuanec, M. Carrington, S. O'Brien, J. M. Andrieu, F. Schachter, D. Zagury, J. Rappaport, C. Winkler, G. W. Nelson, and J. F. Zagury. 1999. New class I and II HLA alleles strongly associated with opposite patterns of progression to AIDS. J. Immunol. 162: 6942-6946.

25. Horton, H., I. Frank, R. Baydo, E. Jalbert, J. Penn, S. Wilson, J. P. McNevin, M. D. McSweyn, D. Lee, Y. Huang, S. C. De Rosa, and M. J. McEIrath. 2006. Preservation of T-cell proliferation restricted by protective HLA alleles is critical for immune control of HIV-1 infection. J. Immunol. 177:7406-7415.

26. Hubert, J. B., M. Burgard, E. Dussaix, C. Tamalet, C. Deveau, J. Le Chenadec, M. L. Chaix, E. Marchadier, J. L. Vilde, J. F. Delfraissy, L. Meyer, Rouzioux, et al. 2000. Natural history of serum HIV-1 RNA levels in 330 patients with a known date of infection. 14:123-131.

27. Jansen, C. A., S. Kostense, K. Vandenberghe, N. M. Nanlohy, I. M. De Cuyper, E. Piriou, E. H. Manting, F. Miedema, and D. van Baarle. 2005. High responsiveness of HLA-B57-restricted Gag-specific CD8 ${ }^{+} \mathrm{T}$ cells in vitro may contribute to the protective effect of HLA-B57 in HIV-infection. Eur. J. Immunol. 35:150-158.

28. Jansen, C. A., D. van Baarle, and F. Miedema. 2006. HIV-specific $\mathrm{CD}^{+}{ }^{+} \mathrm{T}$ cells and viremia: who's in control? Trends Immunol. 27:119-124.

29. Kaslow, R. A., M. Carrington, R. Apple, L. Park, A. Munoz, A. J. Saah, J. J. Goedert, C. Winkler, S. J. O'Brien, C. Rinaldo, R. Detels, W. Blattner, J. Phair, H. Erlich, and D. L. Mann. 1996. Influence of combinations of human major histocompatibility complex genes on the course of HIV-1 infection. Nat. Med. 2:405-411.

30. Kiepiela, P., K. Ngumbela, C. Thobakgale, D. Ramduth, I. Honeyborne, E. Moodley, S. Reddy, C. de Pierres, Z. Mncube, N. Mkhwanazi, K. Bishop, M. van der Stok, K. Nair, N. Khan, H. Crawford, R. Payne, A. Leslie, J. Prado, A. Prendergast, J. Frater, N. McCarthy, C. Brander, G. H. Learn, D. Nickle, C. Rousseau, H. Coovadia, J. I. Mullins, D. Heckerman, B. D. Walker, and P. Goulder. 2007. $\mathrm{CD} 8^{+}$T-cell responses to different HIV proteins have discordant associations with viral load. Nat. Med. 13:46-53.

31. Kostense, S., K. Vandenberghe, J. Joling, D. Van Baarle, N. Nanlohy, E. Manting, and F. Miedema. 2002. Persistent numbers of tetramer ${ }^{+} \mathrm{CD} 8^{+} \mathrm{T}$ cells, but loss of IFN- $\gamma^{+}$HIV-specific T cells during progression to AIDS. Blood 99:2505-2511

32. Lambotte, O., F. Boufassa, Y. Madec, A. Nguyen, C. Goujard, L. Meyer, C. Rouzioux, A. Venet, and J. F. Delfraissy. 2005. HIV controllers: a homogeneous group of HIV-1-infected patients with spontaneous control of viral replication. Clin. Infect. Dis. 41:1053-1056.

33. Lefrere, J. J., L. Morand-Joubert, M. Mariotti, H. Bludau, B. Burghoffer, J. C. Petit, and F. Roudot-Thoraval. 1997. Even individuals considered as long-term nonprogressors show biological signs of progression after 10 years of human immunodeficiency virus infection. Blood 90:1133-1140.

34. Magierowska, M., I. Theodorou, P. Debre, F. Sanson, B. Autran, Y. Riviere, D. Charron, and D. Costagliola. 1999. Combined genotypes of CCR5, CCR2, SDF1, and HLA genes can predict the long-term nonprogressor status in human immunodeficiency virus-1-infected individuals. Blood 93: 936-941.

35. Maldarelli, F., S. Palmer, M. S. King, A. Wiegand, M. A. Polis, J. Mican, J. A. Kovacs, R. T. Davey, D. Rock-Kress, R. Dewar, S. Liu, J. A. Metcalf, C. Rehm, S. C. Brun, G. J. Hanna, D. J. Kempf, J. M. Coffin, and J. W. Mellors. 2007. ART suppresses plasma HIV-1 RNA to a stable set point predicted by pretherapy viremia. PLoS Pathog. 3:e46.

36. Martin, M. P., X. Gao, J. H. Lee, G. W. Nelson, R. Detels, J. J. Goedert, S. Buchbinder, K. Hoots, D. Vlahov, J. Trowsdale, M. Wilson, S. J. O'Brien, and M. Carrington. 2002. Epistatic interaction between KIR3DS1 and HLA-B delays the progression to AIDS. Nat. Genet. 31:429-434.

37. Migueles, S. A., A. C. Laborico, H. Imamichi, W. L. Shupert, C. Royce, M. McLaughlin, L. Ehler, J. Metcalf, S. Liu, C. W. Hallahan, and M. Connors. 2003. The differential ability of HLA B* $5701^{+}$long-term nonprogressors and progressors to restrict human immunodeficiency virus replication is not 
caused by loss of recognition of autologous viral gag sequences. J. Virol 77:6889-6898.

38. Migueles, S. A., A. C. Laborico, W. L. Shupert, M. S. Sabbaghian, R. Rabin, C. W. Hallahan, D. Van Baarle, S. Kostense, F. Miedema, M. McLaughlin, L. Ehler, J. Metcalf, S. Liu, and M. Connors. 2002. HIV-specific CD8 ${ }^{+}$ $\mathrm{T}$-cell proliferation is coupled to perforin expression and is maintained in nonprogressors. Nat. Immunol. 3:1061-1068.

39. Migueles, S. A., M. S. Sabbaghian, W. L. Shupert, M. P. Bettinotti, F. M Marincola, L. Martino, C. W. Hallahan, S. M. Selig, D. Schwartz, J. Sullivan, and M. Connors. 2000. HLA B*5701 is highly associated with restriction of virus replication in a subgroup of HIV-infected long-term nonprogressors. Proc. Natl. Acad. Sci. USA 97:2709-2714.

40. Mikhail, M., B. Wang, and N. K. Saksena. 2003. Mechanisms involved in non-progressive HIV disease. AIDS Rev. 5:230-244.

41. Ortiz, G. M., M. Wellons, J. Brancato, H. T. Vo, R. L. Zinn, D. E. Clarkson, K. Van Loon, S. Bonhoeffer, G. D. Miralles, D. Montefiori, J. A Bartlett, and D. F. Nixon. 2001. Structured antiretroviral treatment interruptions in chronically HIV-1-infected subjects. Proc. Natl. Acad. Sci USA 98:13288-13293.

42. Pantaleo, G., and R. Koup. 2004. Correlates of immune protection in HIV-1 infection: what we know, what we don't know, what we should know. Nat. Med. 10:806-810.

43. Pantaleo, G., S. Menzo, M. Vaccarezza, C. Graziosi, O. J. Cohen, J. F Demarest, D. Montefiori, J. M. Orenstein, C. Fox, L. K. Schrager, et al. 1995 Studies in subjects with long-term nonprogressive human immunodeficiency virus infection. N. Engl. J. Med. 332:209-216.

44. Papasavvas, E., J. R. Kostman, B. Thiel, M. Pistilli, A. Mackiewicz, A Foulkes, R. Gross, K. A. Jordan, D. F. Nixon, R. Grant, J. F. Poulin, J. M McCune, K. Mounzer, and L. J. Montaner. 2006. HIV-1-specific CD4+ T-cell responses in chronically HIV-1-infected blippers on antiretrovira therapy in relation to viral replication following treatment interruption. J. Clin. Immunol. 26:40-54.

45. Papasavvas, E., G. M. Ortiz, R. Gross, J. Sun, E. C. Moore, J. J. Heymann, M. Moonis, J. K. Sandberg, L. A. Drohan, B. Gallagher, J. Shull, D. F. Nixon, J. R. Kostman, and L. J. Montaner. 2000. Enhancement of human immunodeficiency virus type 1 -specific CD4 and CD8 T-cell responses in chronically infected persons after temporary treatment interruption. J. Infect. Dis. 182:766-775.

46. Pereyra, F., M. M. Addo, D. E. Kaufmann, Y. Liu, T. Miura, A. Rathod, B. Baker, A. Trocha, R. Roenberg, E. Mackey, P. Ueda, Z. Lu, D. Cohen, T. Wrin, C. J. Petropoulos, E. S. Roenberg, and B. Walker. 2008. Genetic and Immunologic heterogeneity among persons who control HIV infection in the absence of therapy. J. Infect. Dis. 197:563-571.

47. Qi, Y., M. P. Martin, X. Gao, L. Jacobson, J. J. Goedert, S. Buchbinder, G. D. Kirk, S. J. O'Brien, J. Trowsdale, and M. Carrington. 2006. KIR/HLA pleiotropism: protection against both HIV and opportunistic infections. PLoS Pathog. 2:e79.

48. Ramratnam, B., J. E. Mittler, L. Zhang, D. Boden, A. Hurley, F. Fang, C. A Macken, A. S. Perelson, M. Markowitz, and D. D. Ho. 2000. The decay of the latent reservoir of replication-competent HIV-1 is inversely correlated with the extent of residual viral replication during prolonged anti-retroviral therapy. Nat. Med. 6:82-85.

49. Rodes, B., C. Toro, E. Paxinos, E. Poveda, M. Martinez-Padial, J. M. Benito, V. Jimenez, T. Wrin, S. Bassani, and V. Soriano. 2004. Differences in disease progression in a cohort of long-term non-progressors after more than 16 years of HIV-1 infection. AIDS 18:1109-1116.

50. Rosenberg, E. S., J. M. Billingsley, A. M. Caliendo, S. L. Boswell, P. E. Sax, S. A. Kalams, and B. D. Walker. 1997. Vigorous HIV-1-specific CD4 ${ }^{+}$T-cell responses associated with control of viremia. Science 278:1447-1450.

51. Sacha, J. B., C. Chung, E. G. Rakasz, S. P. Spencer, A. K. Jonas, A. T. Bean, W. Lee, B. J. Burwitz, J. J. Stephany, J. T. Loffredo, D. B. Allison, S. Adnan, A. Hoji, N. A. Wilson, T. C. Friedrich, J. D. Lifson, O. O. Yang, and D. I. Watkins. 2007. Gag-specific $\mathrm{CD}^{+} \mathrm{T}$ lymphocytes recognize infected cells before AIDS-virus integration and viral protein expression. J. Immunol. 178:2746-2754.

52. Sacha, J. B., C. Chung, J. Reed, A. K. Jonas, A. T. Bean, S. P. Spencer, W. Lee, L. Vojnov, R. Rudersdorf, T. C. Friedrich, N. A. Wilson, J. D. Lifson, and D. I. Watkins. 2007. Pol-specific $\mathrm{CD}^{+} \mathrm{T}$ cells recognize simian immunodeficiency virus-infected cells prior to Nef-mediated major histocompatibility complex class I downregulation. J. Virol. 81:11703-11712.

53. Saez-Cirion, A., C. Lacabaratz, O. Lambotte, P. Versmisse, A. Urrutia, F. Boufassa, F. Barre-Sinoussi, J. F. Delfraissy, M. Sinet, G. Pancino, and A. Venet. 2007. HIV controllers exhibit potent CD8 T-cell capacity to suppress HIV infection ex vivo and peculiar cytotoxic T lymphocyte activation phenotype. Proc. Natl. Acad. Sci. USA 104:6776-6781.

54. Scorza Smeraldi, R, G. Fabio, A. Lazzarin, N. B. Eisera, M. Moroni, and C. Zanussi. 1986. HLA-associated susceptibility to acquired immunodeficiency syndrome in Italian patients with human-immunodeficiency-virus infection. Lancet ii:1187-1189.

55. Siliciano, J. D., J. Kajdas, D. Finzi, T. C. Quinn, K. Chadwick, J. B. Margolick, C. Kovacs, S. J. Gange, and R. F. Siliciano. 2003. Long-term follow-up studies confirm the stability of the latent reservoir for HIV-1 in resting $\mathrm{CD}^{+}{ }^{+} \mathrm{T}$ cells. Nat. Med. 9:727-728.

56. Ullum, H., A. Cozzi Lepri, K. Bendtzen, J. Victor, P. C. Gotzsche, A. N. Phillips, P. Skinhoj, and B. Klarlund Pedersen. 1997. Low production of interferon gamma is related to disease progression in HIV infection: evidence from a cohort of 347 HIV-infected individuals. AIDS Res. Hum. Retrovir. 13:1039-1046.

57. Vento, S., M. Lanzafame, M. Malena, G. Tositti, F. Cainelli, E. Concia, and G. Masiero. 2004. Can we really identify HIV-1 long-term nonprogressors? J. Acquir. Immune Defic. Syndr. 37:1218-1219.

58. Yu, X. G., M. Lichterfeld, S. Chetty, K. L. Williams, S. K. Mui, T. Miura, N. Frahm, M. E. Feeney, Y. Tang, F. Pereyra, M. X. Labute, K. Pfafferott A. Leslie, H. Crawford, R. Allgaier, W. Hildebrand, R. Kaslow, C. Brander, T. M. Allen, E. S. Rosenberg, P. Kiepiela, M. Vajpayee, P. A Goepfert, M. Altfeld, P. J. Goulder, and B. D. Walker. 2007. Mutually exclusive T-cell receptor induction and differential susceptibility to human immunodeficiency virus type 1 mutational escape associated with a two-amino-acid difference between HLA class I subtypes. J. Virol. 81: 1619-1631. 